\title{
Liver regeneration and aging: a review
}

\author{
NUCCI, R. A. B. ${ }^{1}{ }^{*}$ TEODORO, A. C. S. ${ }^{1}$ and GAMA, E. F. ${ }^{2}$ \\ ${ }^{1}$ Laboratory of Morphoquantitative Studies and Immunohistochemistry, Aging Sciences, \\ Universidade São Judas Tadeu - USJT, Rua Taquari, 546, Mooca, CEP 03166-000, São Paulo, SP, Brazil \\ ${ }^{2}$ Laboratory of Morphoquantitative Studies and Immunohistochemistry, Department of Physical Education, \\ Universidade São Judas Tadeu - USJT, Rua Taquari, 546, Mooca, CEP 03166-000, São Paulo, SP, Brazil \\ *E-mail: r.aparecido.nucci@uol.com.br
}

\begin{abstract}
With the advance of age, a clinically significant change is a marked decline in the rate of hepatic regeneration. Many studies described the mechanisms involved in the hepatic regenerative process with experimental procedures such as partial hepatectomy. The aim of the present study was to elucidate the molecular and cellular mechanisms involved in liver regeneration due to partial hepatectomy and the effects of aging on these mechanisms. We used PubMed, MEDLINE and Scholar Google databases investigating the following keywords without restrictions: liver, regeneration, aging. We included research studies (animal and humans) and reviews published in English language that were related to the liver regeneration and the process of aging. The regeneration on liver involves multiple cellular processes and a complex interaction with cytokines and growth factors. The aging process affects liver causing a delay on its regeneration. In a clinical setting, the decline of hepatic regenerative capacity could be considered an important concern, because most of the elderly use different medications which could provide a liver injury, as well as, one of the methods used to remove neoplastic cells is the partial hepatectomy which depends of the individual regenerative capacity.
\end{abstract}

Keywords: liver, regeneration, aging, review.

\section{Introduction}

Regeneration is the reconstitution of a structure that has been damaged or suffered an injury (FAUSTO, CAMPBELL and RIEHLE, 2006). With the advance of age, a clinically significant change is a marked decline in the rate of hepatic regeneration (BIONDO-SIMÕES, MATIAS, MONTIBELLER et al., 2006; SCHMUCKER and SANCHEZ, 2011). Compromise liver regeneration in the elderly would increase the mortality due to liver disease or liver injury (REGEV and SCHIFF, 2001).

One of the most used methods to remove neoplastic cells in humans is the partial hepatectomy, which is also used in experiments with rodents to analyze the mechanisms of liver regeneration (HIGGINS and ANDERSON, 1931; BIONDO-SIMÕES, MATIAS, MONTIBELLER et al., 2006; FAUSTO, CAMPBELL and RIEHLE, 2006; MICHALOPOULOS, 2007; MITCHELL and WILLENBRING, 2008).

The knowledge about the molecular and cellular mechanisms of liver regeneration is both conceptually important and directly relevant to clinical problems (FAUSTO, CAMPBELL and RIEHLE, 2006), as well as, the effects of aging on this mechanisms (SCHMUCKER and SANCHEZ, 2011).

The aim of the present study was to elucidate the molecular and cellular mechanisms involved in liver regeneration due to partial hepatectomy and the effects of aging on these mechanisms.

\section{Materials and Methods}

This review was conducted in December 2015 by the use of PubMed (www.pubmed.nl), MEDLINE and Scholar Google databases investigating the following keywords without restrictions: liver, regeneration, aging. We included research studies (animal and humans) and reviews published in English language that were related to the liver regeneration and the process of aging.

\section{Results}

\subsection{Liver regeneration}

In biological terms, regeneration means the reconstitution of a structure that has been damaged or suffered an injury (FAUSTO, CAMPBELL and RIEHLE, 2006). However, liver regeneration is technically a process of compensatory growth which liver expands in mass to compensate for lost tissue (BARBASON, HERENS, ROBAYE et al., 1994; MICHALOPOULOS and DEFRANCES, 1997; FAUSTO, CAMPBELL and RIEHLE, 2006).

The loss of liver mass can be induced by chemical substances that lead to an inflammatory response which will provide the regenerative response (GAGLIANO, GRIZZI and ANNONI, 2007; MICHALOPOULOS, 2007); or by performing a surgical procedure which removes $2 / 3$ of the liver mass, and is commonly used in rodents (rats and mice) as an experimental procedure. This technique known as $2 / 3$ partial hepatectomy $(\mathrm{PHx})$, which is also used in humans to remove solitary liver metastases or repair trauma via chemicals (HIGGINS and ANDERSON, 1931; MICHALOPOULOS, 2007; MITCHELL and WILLENBRING, 2008). PHx is the most commonly used procedure to analyze the regenerative process on liver in experimental models (HIGGINS and ANDERSON, 1931; BEYER, SHERMAN and ZIEVE, 1991; BIONDO-SIMÕES, MATIAS, MONTIBELLER et al., 2006; MICHALOPOULOS, 
2007; MITCHELL and WILLENBRING, 2008; UMEDA, HIRAMOTO and IMAI, 2015).

The process of regeneration on liver involves multiple cellular processes and a complex interaction with cytokines and growth factors (TARLÁ, RAMALHO, RAMALHO et al., 2006). The importance of cytokine network during the initiation of liver regeneration includes: serum levels of tumor necrosis factor (TNF) and interleukin-6 (IL-6) after PHx (AKERMAN, COTE, YANG et al., 1992; TRAUTWEIN, RAKEMANN, NIEHOF et al., 1996; IWAI, CUI, KITAMURA et al., 2001); and activation of the nuclear factor-kappa B (NF-kB) and signal transducer and activator of transcription 3 (STAT3) (CRESSMAN, DIAMOND and TAUB, 1995; FITZGERALD, WEBBER, DONOVAN et al., 1995).

The cytokine network is initiated through the binding of TNF to type I TNF-receptor (TNFRI), a membrane receptor, leading to activation of NF-kB in nonparenchymal cells (NPCs), such as Kuppfer cells, production of IL-6, and activation of STAT3 in hepatocytes (AKERMAN, COTE, YANG et al., 1992; CRESSMAN, DIAMOND and TAUB, 1995; FITZGERALD, WEBBER, DONOVAN et al., 1995; TRAUTWEIN, RAKEMANN, NIEHOF et al., 1996; IWAI, CUI, KITAMURA et al., 2001; FAUSTO, CAMPBELL and RIEHLE, 2006). One of the mechanisms that could trigger the activation of this network is the molecule of lipopolysaccharide (LPS), which is released from enteric bacteria into the portal circulation (CORNELL, 1985).

Cytokine network acts as the first phase of the liver regeneration leading the hepatocytes cell cycle from G0 to Gl (TAUB, 2004; MICHALOPOULOS, 2007). Cell cycle progression is then driven by growth factors, such as hepatocyte growth factor (HGF) and the epidermal growth factor (EGF), which override a restriction point in late Gl (FAUSTO, CAMPBELL and RIEHLE, 2006).

HGF is produced by mesenchymal cells as stellate cells, and its effects are multiple in the organism ranging from mitogenic to morphogenic effects (TAUB, 2004; MICHALOPOULOS and DEFRANCES, 1997; FAUSTO, CAMPBELL and RIEHLE, 2006; KORDES, SAWITZA, GÖTZE et al., 2014). Stimulation of the tyrosine kinase receptors for HGF (c-met), and the EGF ligands receptor (EGFR), such as transforming growth factor alpha (TGF $\alpha$ ), heparin-binding EGF-like growth factor (HB-EGF), and amphiregulin (AR), activates numerous intracellular signaling pathways in hepatocytes that regulate transcription factors involved in liver regeneration from late Gl to phase S (TAUB, 2004; FAUSTO, CAMPBELL and RIEHLE, 2006). Cooperation between cytokine and growth factor signaling activates pathways that are needed for hepatocyte survival, growth, and proliferation after PHx or another injury (MEAD and FAUSTO, 1989; FAUSTO, CAMPBELL and RIEHLE, 2006). The interaction between cytokines and growth factor were demonstrated in Figure 1.

At the end of regeneration, the size of the liver lobules is remarkably larger, as well as its volume, and the thickness of the hepatocyte plates is almost twice the size of the normal one cell thickness (MICHALOPOULOS and DEFRANCES, 1997).

\subsection{Role of aging on liver regeneration}

A clinically significant age-related change is a marked decline in the rate of hepatic regeneration (BIONDO-SIMÕES, MATIAS, MONTIBELLER et al., 2006; SCHMUCKER and SANCHEZ, 2011). We can see at Figure 2 the liver volume percentage after PHx in young and old rats.

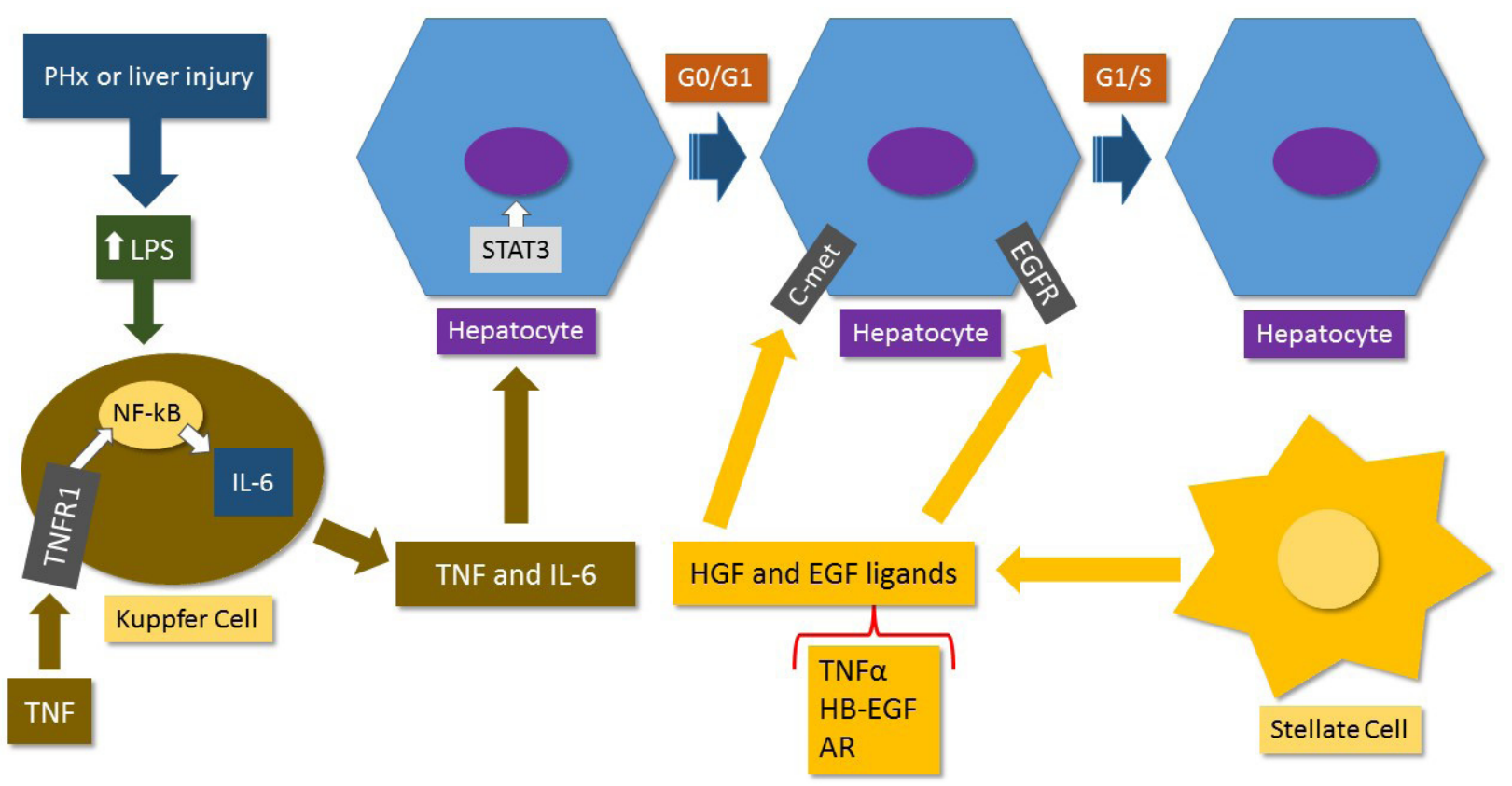

Figure 1. Cytokines and growth factors involved in the liver regeneration (adapted from TAUB, 2004 and FAUSTO, CAMPBELL and RIEHLE, 2006 illustrations). PHx = partial hepatectomy; LPS = lipopolysaccharide; TNF = tumor necrosis factor; TNFRI = type I TNF-receptor; NF-kB = nuclear factor-kappa B; IL-6 = interleukin-6; STAT3 = signal transducer and activator of transcription 3; $\mathrm{HGF}=$ hepatocyte growth factor; c-met = HGF-receptor; EGF = epidermal growth factor; TGF $\alpha=$ transforming growth factor alpha; $\mathrm{HB}-\mathrm{EGF}=$ heparin-binding EGF-like growth factor; $\mathrm{AR}=$ amphiregulin; EGFR = EGF ligands receptor. 


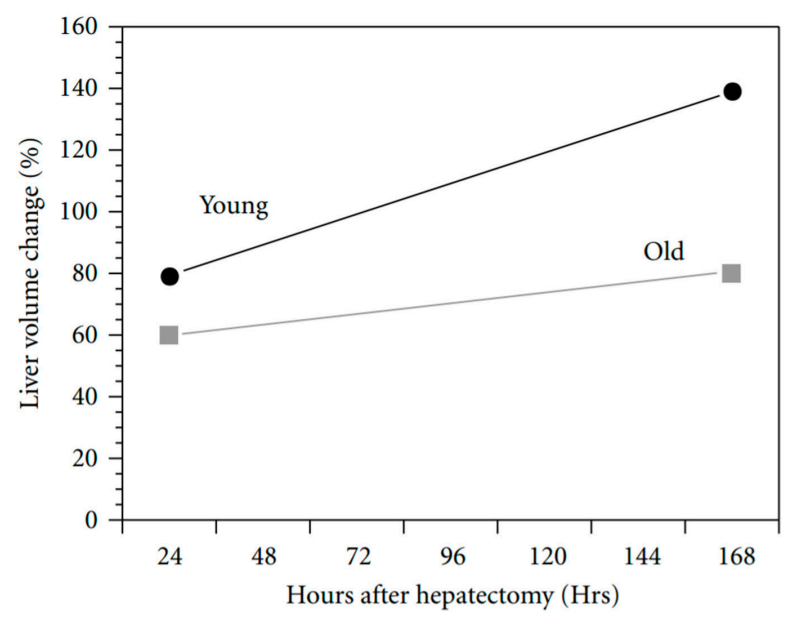

Figure 2. Effect of animal age on liver volume at two intervals following $\mathrm{PHx}$ in young and old rats (data derived from BIONDO-SIMÕES, MATIAS, MONTIBELLER et al., 2006, and adapted from SCHMUCKER and SANCHEZ, 2011).

The concern about compromise liver regeneration in the elderly is the marked increase in mortality due to liver disease, for example hepatocellular carcinoma, or liver injury by medications in elderly subjects in comparison to younger populations (REGEV and SCHIFF, 2001; HUNG and GUY, 2015). Regev and Schiff (2001) reported 3-5-fold increases in deaths due to liver diseases in the over 65 years old population versus those under 45 years of age.

PHx have been largely used to remove neoplastic cells in elderly patients (HUNG and GUY, 2015). Nonetheless, Schmucker and Sanchez (2011), in a review, showed that fewer hepatocytes in senescent animals and elderly humans enter in S-phase after PHx. Sawada (1989) demonstrated that hepatocyte proliferative response to EGF was markedly decreased in old animals which suggested that aging impaired the responsiveness of the cells in old rats to growth factors. However, Marti (1993) demonstrated in hepatocyte plasma membranes isolated from intact livers a $60 \%$ age-related decline in EGF binding to hepatocyte membranes (via EGFR) in rats. On the other hand, Ishigami, Reed and Roth. (1993) reported the absence of any age-related change in EGF binding capacity in primary hepatocyte cultures, but did report a marked decline in EGF-induced DNA synthesis. Despite of the differences in the results, all studies indicate that the liver regeneration delay in elderly is related to the growth factors, mainly EGF.

\section{Conclusion}

Most of the knowledge about the molecular and cellular mechanisms of liver regeneration is both conceptually important and directly relevant to clinical problems.

In a clinical setting, the decline of hepatic regenerative capacity could be considered an important concern, because most of the elderly use different medications which could provide a liver injury, as well as, one of the methods used to remove neoplastic cells is the partial hepatectomy which depends of the individual regenerative capacity.

\section{References}

AKERMAN, P., COTE, P., YANG, SQ., MCCLAIN, C., NELSON, S., BAGBY, GJ. and DIEHL, AM. Antibodies to tumor necrosis factoralpha inhibit liver regeneration after partial hepatectomy. American Journal of Physiology. Gastrointestinal and Liver Physiology, 1992, vol. 263, n. 4, p. G579-G585. PMid:1415718.

BARBASON, H., HERENS, C., ROBAYE, B., MILIS, G., SULON, J., BOUZAHZAH, B. and VANCANTFORT, J. Importance of cell kinetics rhythmicity for the control of cell proliferation and carcinogenesis in rat liver. In Vivo (Athens, Greece), 1994, vol. 9, n. 6, p. 539-548. PMid:8726799.

BEYER, HS., SHERMAN, R. and ZIEVE, L. Aging is associated with reduced liver regeneration and diminished thymidine kinase mRNA content and enzyme activity in the rat. The Journal of Laboratory and Clinical Medicine, 1991, vol. 117, n. 2, p. 101-108. PMid:1704406.

BIONDO-SIMÕES, MLP., MATIAS, JEF., MONTIBELLER, GR., SIQUEIRA, LCD., NUNES, EDS. and GRASSI, CA. Effect of aging on liver regeneration in rats. Acta Cirurgica Brasileira, 2006, vol. 21, n. 4, p. 197-202. PMid:16862337. http://dx.doi.org/10.1590/ S0102-86502006000400002.

CORNELL, RP. Gut-derived endotoxin elicits hepatotrophic factor secretion for liver regeneration. American Journal of Physiology, 1985, vol. 249, n. 5, p. R551-R562. PMid:2865902.

CRESSMAN, DE., DIAMOND, RH. and TAUB, R. Rapid activation of the Stat3 transcription complex in liver regeneration. Hepatology (Baltimore, Md.), 1995, vol. 21, n. 5, p. 1443-1449. PMid:7737651. http://dx.doi.org/10.1002/hep.1840210531.

FAUSTO, N., CAMPBELL, JS. and RIEHLE, K. J. Liver regeneration. Hepatology (Baltimore, Md.), 2006, vol. 43, n. S1, supplement 1, p. S45-S53. PMid:16447274. http://dx.doi.org/10.1002/hep.20969.

FITZGERALD, MJ., WEBBER, EM., DONOVAN, JR. and FAUSTO, $\mathrm{N}$. Rapid DNA binding by nuclear factor kappa B in hepatocytes at the start of liver regeneration. Cell Growth \& Differentiation: The Molecular Biology Journal of the American Association for Cancer Research, 1995, vol. 6, n. 4, p. 417-427. PMid:7794809.

GAGLIANO, N., GRIZZI, F. and ANNONI, G. Mechanisms of aging and liver functions. Digestive Diseases (Basel, Switzerland), 2007, vol. 25, n. 2, p. 118-123. PMid:17468546. http://dx.doi. org/10.1159/000099475.

HIGGINS, GM. and ANDERSON, RM. Experimental pathology of the liver. Archives of Pathology, 1931, vol. 12, p. 186-202.

HUNG, AK. and GUY, J. Hepatocellular carcinoma in the elderly: meta-analysis and systematic literature review. World Journal of Gastroenterology, 2015, vol. 21, n. 42, p. 12197-12210. PMid:26576104. http://dx.doi.org/10.3748/wjg.v21.i42.12197.

ISHIGAMI, A., REED, TD. and ROTH, GS. Effect of aging on EGF stimulated DNA synthesis and EGF receptor levels in primary cultured rat hepatocytes. Biochemical and Biophysical Research Communications, 1993, vol. 196, n. 1, p. 181-186. PMid:8216291. http://dx.doi. org/10.1006/bbrc.1993.2232.

IWAI, M., CUI, TX., KITAMURA, H., SAITO, M. and SHIMAZU, T. Increased secretion of tumour necrosis factor and interleukin 6 from isolated, perfused liver of rats after partial hepatectomy. Cytokine, 2001, vol. 13, n. 1, p. 60-64. PMid:11145844. http://dx.doi. org/10.1006/cyto.2000.0797.

KORDES, C., SAWITZA, I., GÖTZE, S., HEREBIAN, D. and HÄUSSINGER, D. Stellate cells are mesenchymal stem cells. European Journal of Medical Research, 2014, vol. 19, n. 1, supplement 1, p. S6. http://dx.doi.org/10.1186/2047-783X-19-S1-S6.

MARTI, U. Handling of epidermal growth factor and number of epidermal growth factor receptors are changed in aged male rats. 
Hepatology (Baltimore, Md.), 1993, vol. 18, n. 6, p. 1432-1436. PMid:8244269. http://dx.doi.org/10.1002/hep.1840180623.

MEAD, JE. and FAUSTO, N. Transforming growth factor alpha may be a physiological regulator of liver regeneration by means of an autocrine mechanism. Proceedings of the National Academy of Sciences of the United States of America, 1989, vol. 86, n. 5, p. 1558-1562. PMid:2922399. http://dx.doi.org/10.1073/pnas.86.5.1558.

MICHALOPOULOS, GK. and DEFRANCES, MC. Liver regeneration. Science, 1997, vol. 276, n. 5309, p. 60-66. PMid:9082986. http:// dx.doi.org/10.1126/science.276.5309.60.

MICHALOPOULOS, GK. Liver regeneration. Journal of Cellular Physiology, 2007, vol. 213, n. 2, p. 286-300. PMid:17559071. http:// dx.doi.org/10.1002/jcp.21172.

MITCHELL, C. and WILLENBRING, H. A reproducible and well-tolerated method for $2 / 3$ partial hepatectomy in mice. Nature Protocols, 2008, vol. 3, n. 7, p. 1167-1170. PMid:18600221. http:// dx.doi.org/10.1038/nprot.2008.80.

REGEV, A. and SCHIFF, ER. Liver disease in the elderly. Gastroenterology Clinics of North America, 2001, vol. 30, n. 2, p. 547-563, x-xi. PMid:11432305. http://dx.doi.org/10.1016/S0889-8553(05)70195-3.

SAWADA, N. Hepatocytes from old rats retain responsiveness of c-myc expression to EGF in primary culture but do not enter $S$ phase. Experimental Cell Research, 1989, vol. 181, n. 2, p. 584-588. PMid:2784388. http://dx.doi.org/10.1016/0014-4827(89)90115-8.
SCHMUCKER, DL. and SANCHEZ, H. Liver regeneration and aging: a current perspective. Current Gerontology and Geriatrics Research, 2011, vol. 2011, p. 1-9. PMid:21912543. http://dx.doi. org $/ 10.1155 / 2011 / 526379$.

TARLÁ, MR., RAMALHO, FS., RAMALHO, LNZ., SILVA, TC., BRANDÃO, DF., FERREIRA, J. and ZUCOLOTO, S. A molecular view of liver regeneration. Acta Cirurgica Brasileira, 2006, vol. 21, supplement 1, p. 58-62. PMid:17013516.

TAUB, R. Liver regeneration: from myth to mechanism. Nature Reviews: Molecular Cell Biology, 2004, vol. 5, n. 10, p. 836-847. PMid:15459664. http://dx.doi.org/10.1038/nrml489.

TRAUTWEIN, C., RAKEMANN, T., NIEHOF, M., ROSE-JOHN, $S$. and MANNS, MP. Acute phase response factor, increased binding, and target gene transcription during liver regeneration. Gastroenterology, 1996, vol. 110, n. 6, p. 1854-1862. PMid:8964411. http://dx.doi. org/10.1053/gast.1996.v110.pm8964411.

UMEDA, M., HIRAMOTO, M. and IMAI, T. Partial hepatectomy induces delayed hepatocyte proliferation and normal liver regeneration in ovariectomized mice. Clinical and Experimental Gastroenterology, 2015, vol. 8, p. 175-182. PMid:26170710.

Received November 13, 2015 Accepted November 8, 2016 